\title{
P066. Migraine with aura in the locker room: 4 case reports
}

\author{
Laura Bernetti ${ }^{*}$, lenia Corbelli, Michele Romoli, Chiara Bedetti, Elona Brahimi, Paola Sarchielli, Paolo Calabresi \\ From Abstracts from the 1st Joint ANIRCEF-SISC Congress \\ Rome, Italy. 29-31 October 2015
}

We describe four cases of young men 19, 21, 23 and 25 years old with recurrent episodes of migraine with aura occurring shortly after the end of physical activities (football match, swimming, gym training, physical education activities at school), when they were in the locker room.

Since these types of symptoms could mime some important pathologies in approximately $10 \%$ of these headaches, it is mandatory, in this kind of patient, to exclude a form of secondary headache [1]. No other subtypes of headache, or head trauma were reported by the patients.

It is well known that physical activity can lead to an aggravation of the intensity of the headache, but the pathophysiological relationship between exertion and aura is unknown and still debated.

There are anecdotal reports of episodes of migraine preceded by head trauma and visual symptoms (with a past history of non-sports-related migraine) [2,3], migraine prodrome symptoms after unusually strenuous running with no following head pain [4] or recurrent attacks of hemiplegic migraine induced only by exertion [5].

According to the present version of the International Classification of Headache Disorders, (ICHD-III beta), the headache subtype presented by the four patients fulfilled criteria for "migraine with aura" (ICHD-III beta code: 1.2) and for "primary exertional headache" (pulsating headache, lasting from 5 minutes to 48 hours, brought on by and occurring only during or after physical exertion; ICHD-III beta code: 4.2) [6].

To date, in the IHS Classification (ICHD-III beta), there is no mention of sport/exercise-induced migraine with aura episodes as primary headache, and there is the need of a double diagnosis, although there are anecdotal

\footnotetext{
* Correspondence: laura.bernetti@libero.it

Headache Centre, Neurologic Clinic, "S. M. della Misericordia" Hospital, University of Perugia, Perugia, Italy
}

\section{SpringerOpen ${ }^{\circ}$}

(c) 2015 Bernetti et al. This is an Open Access article distributed under the terms of the Creative Commons Attribution License (http:// creativecommons.org/licenses/by/4.0), which permits unrestricted use, distribution, and reproduction in any medium, provided the original work is properly cited. The Creative Commons Public Domain Dedication waiver (http://creativecommons.org/publicdomain/ zero/1.0/) applies to the data made available in this article, unless otherwise stated. reports of attacks of migraine with aura shortly after sports.

Written informed consent to publish was obtained from the patient(s).

Published: 28 September 2015

\section{References}

1. Nadelson C: Sport and exercise-induced migraines. Curr Sports Med Rep 2006, 5(1):29-33.

2. Espir ML, Hodge IL, Matthews PH: Footballer's migraine. Br Med J 1972, 3(5822):352.

3. Gibbs N: Common rugby league injuries. Recommendations for treatment and preventative measures. Sports Med 1994, 18(6):438-450.

4. Thompson JK: Exercise-induced migraine prodrome symptoms. Headache 1987, 27(5):250-251.

5. Razavi M, Razavi B, Fattal D, Afifi A, Adams HP Jr: Hemiplegic migraine induced by exertion. Arch Neurol 2000, 57(9):1363-1365.

6. Headache Classification Committee of the International Headache Society (IHS): The International Classification of Headache Disorders, 3rd edition (beta version). Cephalalgia 2013, 33(9):629-808.

doi:10.1186/1129-2377-16-S1-A169

Cite this article as: Bernetti et al:: P066. Migraine with aura in the locker room: 4 case reports. The Journal of Headache and Pain 2015 16(Suppl 1): A169.

Submit your manuscript to a SpringerOpen ${ }^{\circ}$ journal and benefit from:

- Convenient online submission

- Rigorous peer review

- Immediate publication on acceptance

- Open access: articles freely available online

- High visibility within the field

- Retaining the copyright to your article

Submit your next manuscript at $>$ springeropen.com 